\title{
The Joint Effect of Accounting Knowledge and Self-serving Attribution on the Voluntary Disclosure of Management Earnings Forecast
}

\author{
Kanjana Phonsumlissakul*, Juthathip Audsabumrungrat and \\ Supol Durongwatana
}

\begin{abstract}
Manuscript type: Research paper

Research aims: This study investigates the effect of accounting knowledge and self-serving attribution bias on the voluntary disclosure of management earnings forecast.

Design/Methodology/Approach: An experimental design is conducted with 58 business programme graduate students. The participants are placed into two groups: low accounting knowledge and high accounting knowledge. The two groups are then randomly assigned to either the internal or external attribution condition.

Research findings: The results show that managers with high accounting knowledge are more likely to issue management earnings forecasts than those with low accounting knowledge. This study, however, indicates that the willingness to disclose management earnings forecasts is not dependent on the self-serving attribution.
\end{abstract}

\footnotetext{
*Corresponding author: Kanjana Phonsumlissakul has completed his PhD in Accounting at the Department of Accountancy, Chulalongkorn Business School, Chulalongkorn University, Thailand. Email: kanjana.ph558@cbs.chula.ac.th, Kanjanakae@hotmail.com

Juthathip Audsabumrungrat is an Assistant Professor at the Department of Accountancy, Chulalongkorn Business School, Chulalongkorn University, Thailand. Email: juthathip@cbs. chula.ac.th

Supol Durongwatana is an Associate Professor at the Department of Statistics, Chulalongkorn Business School, Chulalongkorn University, Thailand. Email: supol@cbs.chula.ac.th
}

Acknowledgement: This study was supported by the 90th Anniversary of Chulalongkorn University Fund (Ratchadaphiseksomphot Endowment Fund). 
Despite this, the findings illustrate that the joint effect of the accounting knowledge and self-serving attribution will influence the voluntary disclosure of management earnings forecast. Specifically, managers with low accounting knowledge are more likely to withhold information if the cause of the unfavourable performance is due to internal factors. In contrast, they are more willing to disclose their future earnings failure if it is due to external factors. This situation, nevertheless, does not apply to managers with high accounting knowledge who tend to issue future earnings information, regardless of the internal or external factor.

Theoretical contributions/Originality: This study delineates the boundary effect of accounting knowledge and self-serving attribution on management disclosure decisions. The results of this study reveal that self-serving attribution bias influences managers' level of willingness in voluntarily disclosing management earnings forecast, under unfavourable outcomes.

Practitioner/Policy implication: The results of this study also reveal that high accounting knowledge can reduce the effect of self-serving attribution bias on managers' judgment, thereby making it more practical for managers to acquire more accounting knowledge.

Research limitation: This study treats the level of accounting knowledge based on the number of accounting courses taken by the participants rather than testing their accounting knowledge per se.

Keywords: Management Earnings Forecast, Attribution Bias, Accounting Knowledge

JEL Classification: M41

\section{Introduction}

Management earnings forecasts are voluntary managerial disclosures. These disclosures are related to the firm's expected performance, before the actual performance announcement is made (King, Pownall, \& Waymire, 1990). Studies (Han, 2013; Hirst, Koonce, \& Venkataraman, 2008; King et al., 1990) found that the number of management earnings forecasts issued by public companies had increased conspicuously with divergent contents and diverse timing (Kothari, Shu, \& Wysocki, 2009; Miller, 2002; Skinner, 1994). Similarly, management earnings forecasts have been the focus of academic research for decades (e.g., Rogers \& Stocken, 2005; Bozanic, Roulstone, \& Van Buskirk, 2018). It was reported that management forecasts, as compared to other sources, offer rich information to investors. Considering the substantial evidence noted on the importance of management earnings forecasts, this study, therefore 
aims to explore the management's opportunity to withhold or conceal unfavourable future earnings information.

Many factors, such as litigation risk, reputation costs, market reaction and others, affect the firm's voluntary disclosure. These have been documented in prior studies (Kothari et al., 2009; Lev \& Penman, 1990; Skinner, 1994; 1997). Whilst these studies provide insights into the issue of voluntary disclosure, there is still a lack of studies that investigate the characteristics of the decision makers or managers who decide to voluntarily disclose information to the public. On a similar note, Bonner (2008) suggested that individuals with strong knowledge contents are more likely to make better and more informed decisions than those with weak knowledge contents. Considering that accounting is an area of specialised knowledge, it is perceived that an individual's background and knowledge, could impact his/her judgment and decision-making (JDM). Within the accounting education literature, individuals who have received formal accounting training were expected to possess accounting knowledge structures that are dominated by the generally accepted accounting principles (GAAP), which do not generally incorporate opportunity costs within the business resource allocation decision (Vera-Munoz, 1998). This implies that individuals with high accounting knowledge are able to recognise and prioritise the information that is relevant to different decision makers. They would be able to realise that information should be accurately and fairly disclosed to the public. As information providers, they should be accountable to the information users, meaning that disclosed information should be transparent and equitable. Based on these arguments, this study posits that the extent of accounting knowledge could be a factor determining the asymmetric voluntary disclosure behaviour of managers. Although accounting knowledge in voluntary disclosure behaviours is important, it is difficult to measure the extent of its impact. One way to accomplish this is to conduct an experimental research so that researchers could isolate the effect of this particular factor, such as by controlling all other relevant factors.

When disclosing earnings forecasts, firms have the option to explain the cause of the forecasted figures. In relation to this, previous research (Baginski, Hassell, \& Hillison, 2000; Baginski, Hassell, \& Kimbrough, 2004) indicated that there are stronger market reactions when a causal explanation or attribution is given than when there is an absence of attribution. The attribution theory says that individuals tend to provide the explanation by associating it with internal (self) or external (outside 
of self) causes (Heider, 1958; Weiner, 1985) and poor results were likely to be associated with external causes (Baginski et al., 2004; Chen, Han, \& Tan, 2016; Kimbrough \& Wang, 2014). In other words, people tend to explain the causes in ways that "flatter them" or "put them in a good light" (Kimbrough \& Wang, 2014). This principle is referred to as the "self-serving bias". Similarly, within the context of management earnings forecasts, managers rarely coincide earnings disappointments with internal causes. Managers have also been found to engage in selfserving attributions when they are facing earnings disappointment (Kimbrough \& Wang, 2014) so as to manipulate the investors' perception of their firm's performance. This only occurs when their attribution is not regulated. Thus, prior empirical studies (Baginski et al., 2000; 2004) had not been able to explain whether such attributions were true or that they were part of the strategic management decision. It is difficult to test and validate the link between earnings forecast information and its attribution by using empirical evidence (Baginski et al., 2004). Given this limitation, the current study utilises an experimental method to examine whether self-serving attributions (both internal and external) influence the managers' decision to disclose earnings forecasts and if so, how does this takes place. Studies (Baginski et al., 2004; Chen et al., 2016) suggested that managers tend to provide attributions for firms' negative performance, but they rarely attribute these performances to internal causes. This study, thus assumes that managers will be less willing to disclose disappointing earnings forecasts when they are given internal attributions, as opposed to external attributions.

Taking into account that the extent of one's accounting knowledge and attribution can influence the asymmetric voluntary disclosure behaviour of earnings forecasts among managers, this study, hence, attempts to investigate the joint effect of these two factors. To the best of the researcher's knowledge, previous studies have not ventured into this area yet. The joint effect was examined by conducting an experimental method on 58 participants.

The findings of this study have the potential to contribute to both the voluntary disclosure literature and related regulations, involving forward-looking information. First, it provides the information which highlight that accounting knowledge helps to mitigate the self-serving attribution bias of managers who over-attribute earnings forecasts to internal causes. Based on this, it can be deduced that such accounting knowledge will increase the likelihood of managers issuing management earnings forecasts. Prior auditing literature (Nelson, 1993) had observed 
that auditors with different accounting knowledge could do analytical tasks at different levels. The present study thus provides insights into the strength of using the accounting knowledge as a variable when making decisions about the disclosure of proprietary information. This study further suggests that accounting courses should emphasise on the concepts of equality and fairness in financial reporting. These courses are likely to raise stakeholders' awareness about the importance of accountability. This advantage could also enhance managers' willingness to voluntarily disclose such significant information for the market investors. The strategic disclosure behaviour of withholding future earnings failures also tend to diminish when the accounting knowledge is higher. From the perspective of the regulators, it thus makes practical sense for managers to acquire more accounting knowledge.

Additionally, these findings also contribute to the attribution literature by linking the self-serving attribution from psychology to economic decision-making (e.g., the disclosure of management earnings forecasts). Even though prior research in psychology (Gurevich, Kliger, \& Weiner, 2012) had suggested that causal attribution plays a role in the aforementioned decision, this study demonstrates that causality does not significantly affect decision makers when their decisions could not specify a right or wrong answer. In other words, causal attribution only impacts decision makers when the outcome is justified. Hence, this study extends on prior literature's assertion that self-serving attribution affects individuals' judgments when the task measures the explicit outcomes of the decision makers' choices. Nevertheless, this study extends on previous findings (Baginski et al., 2004; Kimbrough \& Wang, 2014) by stressing that the effect of attribution on managers' propensity to issue future earnings information does not vary across individual's judgments. Instead, self-serving attribution bias is contingent on the individual's background knowledge or characteristics.

\section{Theoretical Background and Hypothesis Development}

\subsection{The Propensity for Earnings Forecast Disclosure}

Earnings forecast disclosure in firms is not mandated by law or regulation. Firms can decide to disclose or not to disclose. Earnings forecast disclosures are of interest to investors; they can also arouse market reactions, upon announcements. Thus, disclosure behaviours vary across firms and timeliness (King et al., 1990; Kothari et al., 2009). 
Many studies have noted the association between the valence of earnings forecast news and management disclosure decisions (Kothari et al., 2009; Roychowdhury \& Sletten, 2012; Skinner, 1994). In this regard, market reactions to negative earnings surprises tend to be large and asymmetric. Therefore, firms can anticipate significant costs to be associated with the missing market expectations.

It has been well established that managers strategically release positive news to show their firms' good performance to the investors and analysts, and also to highlight their own performance among their peers (Kothari et al., 2009; Lev \& Penman, 1990; Miller, 2002). Managers can also manipulate their forecasting behaviours by strategically announcing only the positive forecast news and withholding the negative news during the pre-announcement date. Other studies (Rogers \& Stocken, 2005; Skinner, 1994; 1997) noted that managers disclosed negative earnings forecasts early because they were in fear of the litigation risks involved. Nonetheless, it was also noted by Roychowdhury and Sletten (2012) that some managers appeared to be peculiar with this concern. Whenever the litigation risks were not high enough to induce voluntary disclosures, the possibility of delaying the issuing of bad news was more pronounced (Roychowdhury \& Sletten, 2012). The managers often leak good news prior to their public announcements, whereas bad news were withheld for as long as possible (Kothari et al., 2009). In this regard, firms can be selective in their disclosure timeline, issuing some forecasts for a certain time period, followed by a hibernation period and then a resumption in disclosure (Houston, Lev, \& Tucker, 2010; Rogers \& Stocken, 2005).

In sum, the issuing of earnings forecasts depends on the management's decision since it is a voluntary practice. This makes it a less regulated activity. Specifically, this study focusses on the negative outcomes of omitting future earnings information in disclosures.

\subsection{Accounting Knowledge Content}

In this study, knowledge content refers to the quantity of information that is stored in the long-term memory (Bonner, 2008). The amount of knowledge content and its effect on the quality of judgment and decision-making (JDM), have long been studied in the fields of accounting and psychology (Bonner, 2008). Previous studies (Nelson, 1993; Picur, 2007; Rose \& Rose, 2008; Vera-Munoz, 1998) have suggested that the integration of knowledge structures with information gathered 
from external sources, can be useful in guiding the individual's accounting task in relation to the JDM. Individuals with higher knowledge contents were more likely to employ a knowledge structure that would help them to make suitable decisions (Picur, 2007).

From psychology's definition of knowledge content comes another category of knowledge known as semantic memory, which is related to how concepts are understood and the ability to differentiate what is good or bad. Linked to this are the relevant values of accounting information which individuals have been trained to maintain and to have stored in their long-term memory (Vera-Munoz, 1998), to be used for future tasks. Individuals are expected to realise that the financial information contained within the accounting information is not only meant for the management (internal users), but also for the stakeholders (external users), such as investors, creditors, regulators and others. Contained within those financial information are significant data which are expected to be released to the public, in an equitable and timely fashion. Educators in the field of auditing and internal auditing have been stressing on the concept of corporate governance, transparency and accountability; concepts which managers are expected to acquire. The only issue here is that managers come from different backgrounds with different levels of knowledge due to different exposures. Therefore, their ideas regarding the effectiveness and efficiency of the business operation may vary. Some managers may choose to induce more self-interests, so they might resort to using strategic thinking for their own benefits. Others may not resort to such. Among these managers are Master of Business Administration (MBA) holders who may not have the basic bachelor's degree in accounting. This group of managers are, thus, less likely to appreciate the knowledge of auditing, internal auditing and accounting. They may perceive the accounting information as only one of the many tools to use so as to accomplish their desired results. In this regard, it is possible that managers with MBA degrees may strategically use acceptable accounting methodologies to improve their firms' performance announcement (Fischer \& Rosenzweig, 1995).

According to the literature on motivated reasoning (Kunda, 1990), two types of motives affect the individual's judgment and decisionmaking - accuracy motives and directional motives. When individuals have the accuracy motive, they draw plausible and accurate conclusions (Kunda, 1990). They spend more cognitive efforts on issue-related reasoning. They also consider the relevant information with more 
caution, and they tend to use more complex rules. In particular, it is noted that the individual's semantic knowledge can impact on his/ her judgment and decision-making. Therefore, managers with high accounting knowledge or with an accounting education background, would realise that the accounting information is a necessity for all decision making. Since managers should be accountable to the stakeholders, any significant information disclosed to the public by the managers, should be accurate and fair. Previous literature (Bonner, 2008) has corroborated on the benefits of having accounting knowledge and the ability to complete business-related tasks. Nelson (1993), for instance, suggested that different levels of basic accounting knowledge can also affect the individual's analytical performance in their audit tasks. Rose and Rose (2008) also found that audit committee members with more financial knowledge do not rely on the inadequate explanations gathered from the accounting judgments. Drawing from the motivated reasoning theory, this study posits that the individual's background accounting knowledge could motivate him/her to arrive at a more accurate conclusion when making decisions. It may also raise the individual's awareness of the costs and benefits involved in the strategy selected to make the necessary decision.

The other perspective is the directional motive. Meeting or beating an earnings benchmark is the directional motive that draws managers towards achievements. The motivated reasoning theory states that when people have their own preferences, they will engage in biased reasoning so as to reach their preferences (Kunda, 1990). This means that directional motives can influence people's construction of their attitudes, traits and preferences, all of which can affect their judgments (Kunda, 1990). Specifically, individuals tend to select and use the knowledge structures that support their desired conclusions (Gollwitzer \& Moskowitz, 1996; Kunda, 1990). Therefore, when managers prefer to maintain or boost their stock prices, they would withhold the issuance of unfavourable earnings forecasts, as a way to comply with their preferences. In contrast, they would release positive outcomes early in order to signal their favourable performance to the market (Houston et al., 2010; Kothari et al., 2009; Lang \& Lundholm, 2000; Lev \& Penman, 1990). Sometimes, the management also applies strategic decisions by first putting more efforts into improving the unfavourable performance and withholding such information until a certain threshold is reached (Graham, Harvey, \& Rajgopal, 2005; Kothari et al., 2009). This 
outcome has also been endorsed by Miller (2002) who found that firms strategically increase their disclosure level when they could sustain their strong performance or raise earnings. However, their disclosure level decreases when the firm's earnings deteriorated.

This study assumes that managers with high accounting knowledge would realise the importance of future earnings information, and its relevance to the decision of market participants. Consequently, these managers would be more likely to disclose future earnings information, despite their unfavourable future performance. In contrast, managers with low accounting knowledge would be less likely to disclose their unfavourable future earnings because of the missing market expectations. This study also anticipates that accounting knowledge could reduce managers' bias when evaluating future earnings disappointments. This leads to the first hypothesis:

$\mathrm{H}_{1}$ : Given the unfavourable future earnings, high accounting knowledge managers are more likely to disclose management earnings forecasts than low accounting knowledge managers.

\subsection{Self-serving Attributions}

The theory of attribution states that there are dichotomous constructs of causal attribution - internal and external (Heider, 1958; Weiner, 1985). Internal attribution focusses on a person's dispositional features, such as effort, ability and intention, while external attribution focusses on a person's situational causes of behaviour, such as task difficulty and luck. Individuals have the proclivity to under weigh situational influences and to overweigh dispositional explanations. From the perspective of psychology, it is noted that individuals have a tendency to avoid responsibility when they encounter failures; they attribute such failures to external causes (Miller \& Ross, 1975). In other words, positive events are thus attributed to internal characteristics (e.g., personal skills or efforts) and negative outcomes are attributed to external causes (Miller \& Ross, 1975; Weiner, 1985). This behaviour is referred to as self-serving attribution (Bettman \& Weitz, 1983; Miller \& Ross, 1975).

The application of internal and external attributions within public statements has been well documented in earlier studies (Baginski et al., 2000; 2004; Barton \& Mercer, 2005; Bettman \& Weitz, 1983; Chen et al., 2016). It is observed that many managers tend to engage the attribution 
strategies in order to sway the perceptions of market participants (Barton \& Mercer, 2005; Kimbrough \& Wang, 2014). One study (Kimbrough \& Wang, 2014) argued that managers seemed to provide self-serving attributions in earnings press releases, as a way of managing the investors' perception of the firm's good and bad performance. In fact, earnings forecast reporting could also be biased or unbiased (MerklDavies \& Brennan, 2007). In this regard, it is difficult for investors to distinguish between scrupulous and unscrupulous managers (Lev, 2003).

Returning to the management earnings forecast disclosures, it has been noted that forecast attribution is associated with unfavourable outcomes (Baginski et al., 2000) and maximum forecast forms (Baginski et al., 2004). Prior empirical research (Baginski et al., 2004) noted that earnings forecast disclosure is frequently accompanied by external attributions. In practice, managers rarely attribute their earnings disappointments to internal causes (Chen et al., 2016). It is possible that when managers expect upcoming earnings to be disappointing, they would initially seek out the causes, whether internal or external. However, if the negative outcome is associated with internal causality, the managers might not be willing to disclose their private information. In other words, managers may be bias in issuing earnings forecasts, based on internal and external causality. Despite the extent of studies conducted, prior empirical studies (Baginski et al., 2000; 2004) have not been able to clearly present managers' intent on manipulating the attributions. Therefore, the current study aims to fill the gap by investigating whether or not self-serving attribution bias impacts the manager's propensity to disclose negative earnings forecasts.

Based on the attribution theory, this study posits that the likelihood of issuing an earnings forecast ${ }^{1}$ is influenced by the selfserving attribution bias (internal versus external), especially following an earnings disappointment (i.e., negative news). With unfavourable outcomes, managers with internal self-serving bias are less inclined to issue earnings forecasts. Thus, the second hypothesis is as follows:

$\mathrm{H}_{2}$ : Given the unfavourable future earnings, managers are less likely to disclose management earnings forecast due to internal attribution as compared to external attribution.

\footnotetext{
${ }^{1}$ In this study, attribution is concerned with managers' internal or external attribution (i.e., the research participants) rather than the organisations' attribution.
} 


\subsection{The Joint Effect of Accounting Knowledge and Self-serving Attributions}

The asymmetric payoff to release positive versus negative news is one motivation for managers to abstain from offering voluntary disclosures. Motivated reasoning mechanisms affect personal involvements, including searching for information, creating a representative of the situation, overweighting on evidence, or the reconstruction of information that supports the JDM (Kunda, 1990; Kundra \& Sinclair, 1999). Therefore, people may be bias in their evaluation of the information that is related to the disappointed performance. As mentioned earlier, given the missed market expectations, directional motives could induce the managers into withholding unfavourable earnings information so as to fit into their preference but accuracy motives may mitigate the managers' propensity to omit the bad news information. Therefore, earnings forecast disclosure decisions may depend on the individual's preference.

According to the concept of knowledge content, the individual's accounting knowledge is constructed through his/her prior training and constructive learning. Therefore, people with high accounting knowledge would employ knowledge contents in their JDM. People with greater accounting knowledge have the educational background highlighting the importance of accounting information and accountability. Thus, they are more likely to be concerned about stakeholders than self-preferences. Even though the cause of a disappointing performance may be due to internal or external factors, these individuals would be more willing to voluntarily disclose negative earnings information to the stakeholders, such that actions are brought to light for exhibiting transparent operations and accountability. Consistent with the motivated reasoning framework (Kunda, 1990; Kundra \& Sinclair, 1999), accountability to a party with a known view, will have positive effects on the JDM (Bonner, 2008).

Because of the individual's diverse knowledge due to the individual's background and exposure, it can be deduced that people with less accounting knowledge are more influenced by their own preferences. Self-serving attribution bias emerges when the nature of information diverges from the ego-defensive motives (Miller \& Ross, 1975). Individuals will attribute favourable performances to internal factors (self-enhancing), and unfavourable outcomes will be attributed to external factors (self-protective). In other words, individuals prefer 
to choose the factor that can support their motives. When an earnings forecast is disappointing, these individuals are more likely to seek and refer to external factors that align with their preferences, in support of their failures.

The current study expects that managers with high accounting knowledge are more likely to issue earnings forecasts because they are aware of the importance of full and fair disclosure of information that is relevant to the decision-making processes of capital market participants. Managers with high accounting knowledge are expected to be aware of their accountability to different parties who use the accounting information to make important decisions. Thus, with high accounting knowledge, the likelihood of issuing earnings forecasts among such individuals should be strong, regardless of the internal or external attributions. Attributions should only produce an insignificant difference. In contrast, managers with low accounting knowledge are expected to over-attribute the unfavourable outcomes to internal causes. Thus, less knowledgeable managers who are bias towards the internal attribution are less likely to issue disappointing earnings forecasts than those with external attribution bias (and low accounting knowledge). Based on this, the hypothesis is formulated as:

$\mathrm{H}_{3}$ : Given the unfavourable future earnings, the difference between the likelihood of managers with low and high accounting knowledge issuing management earnings forecast is greater under the internal attribution than under the external attribution.

\section{Research Methodology}

\subsection{Participants}

The participants in this study were 60 Master of Business Administration (MBA) and Master of Accounting (MACC) students in Thailand. There were managers, directors, vice presidents, audit managers, analysts and consultants within this group. The demographic characteristics of the participants and their descriptive statistics are shown in Table 1. Two participants were excluded because they failed the manipulation check questions, leaving the final sample to be 58 participants, comprising 32 MBA students and 26 MACC students. The MBA participants were categorised as low accounting knowledge and the MACC 
participants were categorised as high accounting knowledge. ${ }^{2}$ Of these, 17 participants (29.31 per cent) had previously invested in individual common stocks.

The descriptive statistics shown in Panel B indicate that, on average, those from the low knowledge group have completed 2.75 accounting courses, and those in the high accounting knowledge group have completed 10.15 accounting courses $(p=0.00)$. However, the number of finance and business strategy courses are insignificantly different between the low and high accounting knowledge groups $(p=0.20$ and $p$ $=0.19$, respectively). Thus, the results indicate that the MBA and MACC participants differ only in their accounting knowledge. The mean work experience between the two groups of participants - low accounting knowledge group (6.52 years) and high accounting knowledge group (6.21 years), is also insignificantly different $(p=0.39)$.

To ensure that all participants understand the function and influence of management earnings forecasts on capital markets, and that they have sufficient knowledge to complete the required task, the participants' management earnings forecast knowledge, is also tested through a post-experimental questionnaire which has been adapted from Wang and Tan (2013). The questionnaire is further reviewed for validity by an assistant Vice President who is related to a listed company in Thailand. The questionnaire asks eight questions which focus on the effects of earnings forecasts disclosures (or omission). For example, question (1) asks about management earnings forecasts disclosures influencing analysts' earnings forecast revisions; question (2) asks about the lower or higher management earnings forecasts disclosures vis-à-vis the actual earnings numbers affecting the company's stock price; and question (3) asks about the omission of management earnings forecasts disclosures adversely affecting the management's reputation and transparency. Responses to these questions are based on an 11-point (010) Likert scale, where 0 denotes strongly disagree and 10 strongly agree. The participants, whose average score is below the midpoint (i.e., 5), are excluded from further analysis.

The results indicate that the participants in both groups realise the significance of management forecasts disclosures, and their implications ( $p=0.00$ in all the eight post-experimental questions). Panel B of Table 1

\footnotetext{
2 Seventy per cent of participants with low accounting knowledge hold a non-business undergraduate degree (e.g., engineering, psychology, pharmacy, etc.) and have had no work experience in accounting.
} 
Table 1: Demographic Characteristics and Descriptive Statistics

Panel A: Total sample

\begin{tabular}{|c|c|c|c|c|}
\hline & \multirow[t]{2}{*}{$\mathrm{N}$} & \multirow[t]{2}{*}{$\%$} & \multicolumn{2}{|c|}{$\begin{array}{l}\text { Accounting } \\
\text { Knowledge }\end{array}$} \\
\hline & & & Low & High \\
\hline Initial sample & 60 & & 34 & 26 \\
\hline $\begin{array}{l}\text { Less: Failed manipulation/ } \\
\text { Incomplete questions }\end{array}$ & (2) & & (2) & - \\
\hline Final sample & 58 & 96.67 & 32 & 26 \\
\hline \multicolumn{5}{|l|}{ Gender: (Male/Female) } \\
\hline Male & 21 & 36.21 & 17 & 4 \\
\hline Female & 37 & 63.79 & 15 & 22 \\
\hline \multicolumn{5}{|l|}{ Investment experience } \\
\hline Yes & 17 & 29.31 & 15 & 2 \\
\hline No & 41 & 70.69 & 17 & 24 \\
\hline $\begin{array}{l}\text { Percentage of participants who had } \\
\text { previously invested in common stocks }\end{array}$ & 46.88 & 7.69 & & \\
\hline
\end{tabular}

Panel B: Descriptive statistics - Mean (S.D.)

\begin{tabular}{lccccc}
\hline & \multicolumn{2}{c}{$\begin{array}{c}\text { Accounting } \\
\text { Knowledge }(\mathrm{N}=58)\end{array}$} & $\begin{array}{c}\mathrm{t}- \\
\text { statistics }\end{array}$ & $\begin{array}{c}\mathrm{p}- \\
\text { value }\end{array}$ \\
\cline { 2 - 4 } & Low & High & & \\
\hline Years of work experience & 6.52 & 6.21 & 0.28 & 0.39 \\
& $(1.92)$ & $(5.32)$ & & \\
Management forecast knowledge score & 8.03 & 7.96 & 0.29 & 0.39 \\
& $(0.90)$ & $(0.94)$ & & \\
Background knowledge: & & & & \\
Number of accounting courses & 2.75 & 10.15 & -5.57 & $0.00^{\text {*n* }}$ \\
& $(1.46)$ & $(6.64)$ & & \\
Number of finance courses & 1.90 & 2.34 & -0.85 & 0.20 \\
Number of business strategy courses & $(2.06)$ & $(1.87)$ & & \\
& 0.75 & 1.08 & -0.88 & 0.19 \\
& $(1.50)$ & $(1.32)$ & & \\
\hline
\end{tabular}

Note: a One-tailed equivalent. ${ }^{* * *},{ }^{* *}$, and ${ }^{*}$ denote $1 \%, 5 \%$ and $10 \%$ significance levels, respectively. 
also shows that the mean response of the management earnings forecasts knowledge is insignificantly different between the low and high accounting knowledge groups (8.03 and 7.96, respectively; $p=0.39$, onetailed). The results further indicate that even though the MBA students (low accounting knowledge) have taken fewer accounting courses than the MACC students (high accounting knowledge), they are like the other group. Both groups have adequate knowledge about management earnings forecasts which helped them to complete their tasks.

\subsection{Research Design and Procedures}

This study employs a $2 \times 2$ between-subjects design. The participants are randomly assigned to the attributions (internal or external), which act as an independent variable. They are then assigned as the low-high accounting knowledge groups. This experiment-study ${ }^{3}$ is administered in two parts. The first part presents the background information and summarise the financial data of We Electronics - a hypothetical company listed in the technology industry. The manipulations are introduced in the second part. The additional information describes the cause of the management earnings forecasts (attribution manipulation), the analysts' consensus forecasts and the last quarter's actual earnings (constant numbers of earnings benchmark), and the company's disclosure policy, which emphasise on financial transparency and good corporate governance. Participants are assumed to be holding the posts of executive managers and are given the decision-making authority to disclose or withhold management earnings forecasts information.

Prior to the experiment, participants are informed of the purpose of the study and the required tasks. They are also required to sign a consent form, if agreeable. They are then handed the first envelope (Envelope 1), which contain one of the two attribution-based case materials (internal and external attribution) with questions given on the likelihood of management earnings forecasts disclosures. Upon completion, the first envelope is collected and the second envelope (Envelope 2), containing two sets of questions - manipulation checks and debriefing - is distributed. The second envelope is collected upon

\footnotetext{
${ }^{3}$ This study was conducted with strict review by the Ethics Review Committee for Research Involving Human Research Subjects, Health Science Group, Chulalongkorn University. The participants were protected from harm, and the information was kept confidential. There was minimal risk involved in participating in this study.
} 
completion, and the third envelope (Envelope 3) is distributed. The third envelope contains the post-experimental questionnaire for knowledge test and the demographic questions. The entire task lasts 30 minutes, and participants are each given a 100-Baht (1 USD = THB 33) Starbucks complimentary card for participating.

\subsection{Independent and Dependent Variables}

Participants randomly receive the explanation which states that either the internal or external factors have caused the management's expected earnings (THB 0.90) to be lower than the previous quarter's earnings figure, and the analysts' consensus earnings forecasts (THB 1.10). The internal and external attributions are based on prior studies of attribution locus (Chen et al., 2016). In order to validate the instrument, all the case materials used in this study are pilot tested with 43 other graduate students who do not participate in the main study. The instrument is modified and refined before it is used in the actual experiment.

For the internal attribution, the lower earnings forecast is largely attributed to the company's marketing initiatives. For the external attribution, the lower earnings forecast is largely attributed to the main competitor's new marketing activity. The participants in all the conditions are asked to respond to a dependent variable by indicating the likelihood of issuing a quarterly earnings forecast. Responses are based on an 11-point Likert scale, where 0 denotes, 'not at all likely' and 10 denotes, 'extremely likely'.

\subsection{Covariate Variable}

Previous behavioural research (Bonner, 1990; Bonner \& Lewis, 1990; Libby \& Luft, 1993) in accounting have focussed on the effects of accounting knowledge and years of work experience on performance in the accounting setting. Libby and Luft (1993) noted that individuals with more work experience made better task-related decisions than their counterparts with less work experience. This fact is attributable to the former's higher knowledge store. The current study posits that knowledge and work experience affect the decision-making process differently. To mitigate the confounding effect of work experience on knowledge content, this study thus controlled the years of work experience for the two groups of participants. In addition, this study also 
uses a laboratory experiment to investigate the effects of the accounting knowledge (low versus high) on managers' JDM, with regards to voluntary earnings forecasts disclosure.

\section{Results}

\subsection{Manipulation Checks}

In the manipulation checks, respondents are instructed to answer an 11-point Likert scale ( -5 to 5 ) on the source of attribution, with regards to the management earnings forecast, where $-5,0$ and 5 , would respectively denote internal attribution, neutrality and external attribution. The mean responses are -0.61 for the internal attribution and 2.63 for the external attribution ( $\mathrm{p}=0.00$, one-tailed). The results also indicate that participants are aware that the company's marketing initiative is associated with the internal attribution and the main competitor's new marketing activity was associated with the external attribution. Thus, the manipulation checks are successful.

For attention checks, participants are asked two questions which are related to the earnings forecast numbers in the case materials. They are asked to specify whether the given management earnings forecast is above or below the earnings benchmark (i.e., the previous quarter's earnings figure and analysts' consensus earnings forecast). The results show that as many as 97 per cent of the participants answered both questions correctly.

\subsection{Hypothesis Testing}

In Table 2, Panel A presents the descriptive statistics for the likelihood of issuing a quarterly management earnings forecast, given the low/high accounting knowledge and the internal/external attributions. In Panel $B$, the two-way ANOVA results show that the simple main effect of accounting knowledge on the likelihood of earnings forecast disclosure, is statistically significant $(\mathrm{p}=0.01)$. The mean likelihood of issuing a management earnings forecast for the high accounting knowledge is greater than that of the low accounting knowledge (mean responses $=8.12$ and 7.00, respectively). Therefore, the findings are consistent with $\mathrm{H}_{1}$ - that high accounting knowledge managers are more likely to disclose their unfavourable earnings forecasts than low accounting knowledge managers. 
$\mathrm{H}_{2}$ predicts that the managers are less likely to disclose management earnings forecasts when they resulted from internal causes rather than from external causes. Panel A in Table 2 indicates that the mean responses of the likelihood of issuing management earnings forecast in the presence of internal or external attribution, are 7.25 and

Table 2: The Likelihood of Issuing Management Earnings Forecast

\begin{tabular}{lccc}
\hline \multicolumn{3}{l}{ Panel A: Descriptive Statistics - Mean } & \multicolumn{3}{l}{ Standard Deviation) } \\
\hline Accounting Knowledge & \multicolumn{3}{c}{ Attribution } \\
\cline { 2 - 4 } & Internal & External & Total \\
\hline \multirow{2}{*}{ Low } & $6.33(2.26)$ & $7.59(1.77)$ & $7.00(2.08)$ \\
& $\mathrm{N}=15$ & $\mathrm{~N}=17$ & $\mathrm{~N}=32$ \\
High & $8.31(1.25)$ & $7.92(1.19)$ & $8.12(1.21)$ \\
& $\mathrm{N}=13$ & $\mathrm{~N}=13$ & $\mathrm{~N}=26$ \\
Total & $7.25(2.09)$ & $7.73(1.53)$ & $7.50(1.82)$ \\
& $\mathrm{N}=28$ & $\mathrm{~N}=30$ & $\mathrm{~N}=58$ \\
\hline
\end{tabular}

Panel B: Two-way ANOVA

\begin{tabular}{lcrrcc}
\hline Sources & $\begin{array}{c}\text { Sum of } \\
\text { Squares }\end{array}$ & Df & $\begin{array}{c}\text { Mean } \\
\text { Square }\end{array}$ & F-statistics & p-value \\
\hline Knowledge & 19.20 & 1 & 19.20 & 6.59 & $0.01^{* *}$ \\
Attribution & 2.75 & 1 & 2.75 & 0.94 & 0.34 \\
Knowledge x Attribution & 9.70 & 1 & 9.70 & 3.33 & $0.07^{*}$ \\
Error & 157.42 & 54 & 2.92 & & \\
\hline
\end{tabular}

Panel C: Contrast Tests

\begin{tabular}{|c|c|c|c|}
\hline Sources & $\begin{array}{c}\text { Mean } \\
\text { Difference }\end{array}$ & t-statistics & p-value \\
\hline $\begin{array}{l}\text { The effect of internal attribution } \\
\text { Knowledge - Low vs. High }\end{array}$ & -1.98 & -3.06 & $0.00^{* * *}$ \\
\hline $\begin{array}{l}\text { The effect of external attribution } \\
\text { Knowledge - Low vs. High } \\
\text { One-way ANOVA: } F=3.61 \text {, p-value }=0.02^{* *}\end{array}$ & -0.33 & -0.53 & 0.30 \\
\hline
\end{tabular}

Note: Dependent variable $=$ the likelihood of issuing management earnings forecast. Participants were asked to specify the likelihood of issuing management earnings forecast using an 11-point (0-10) Likert scale, where 0 and 10 respectively denote not at all likely and extremely likely. Total likelihood is $100 \%$. ${ }^{a}$ One-tailed equivalent. ${ }^{* *},{ }^{* *}$ and ${ }^{*}$ denote $1 \%, 5 \%$ and $10 \%$ significance levels, respectively. 
7.73 respectively. Panel B shows that the effect of the attribution on the likelihood of management earnings forecast disclosure, is insignificant $(\mathrm{p}=0.34)$. These findings indicate that the likelihood of issuing management earnings forecasts is the same, regardless of whether the cause is internal or external. This outcome is inconsistent with the expectations of $\mathrm{H}_{2}$. It means that the self-serving attributions do not impact on the willingness of the managers to voluntarily disclose future earnings information.

$\mathrm{H}_{3}$ expects that the difference between the likelihood of issuing management earnings forecasts by managers with low and high accounting knowledge, under the internal attribution, is greater than that of the external attribution. In Table 2, Panel B shows that the joint effect of accounting knowledge and self-serving attributions, are marginally significant $(p=0.07)$. Panel $C$ shows the one-way ANOVA contrast test results between the attributions (internal and external) and low and high accounting knowledge. Under the internal attribution, the mean responses are 6.33 and 8.31 respectively, for the low and high accounting knowledge $(\mathrm{p}=0.00$, one tailed). Under the external attribution, the mean responses are 7.59 and 7.92 respectively, for the low and high accounting knowledge $(\mathrm{p}=0.30$, one tailed). These findings are consistent with $\mathrm{H}_{3}$. Figure 1 illustrates the joint effect of accounting knowledge (low and high) and self-serving attributions (internal and external) on the likelihood of issuing management earnings forecasts.

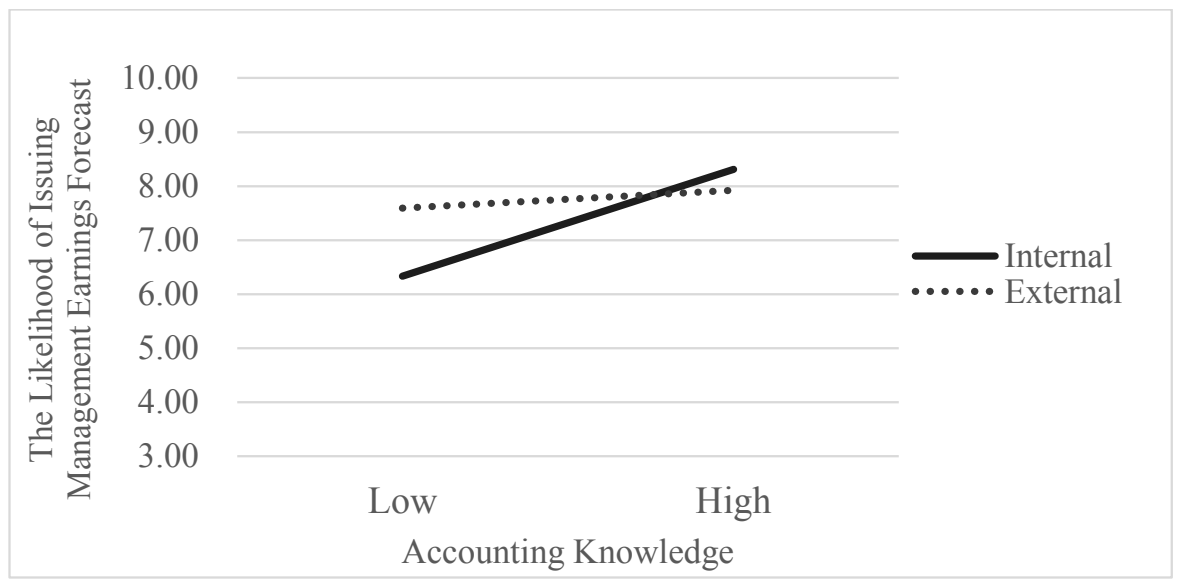

Figure 1: The Joint Effect of Accounting Knowledge and Self-Serving Attributions on the Likelihood of Issuing Management Earnings Forecasts 
Recalling that this study focusses on accounting knowledge and years of work experience and their impact on the individual's performance when completing accounting tasks, an ANCOVA test is conducted so as to mitigate this confounding effect. The test is accomplished by using accounting knowledge and attributions as the independent variables, years of work experience as a covariate, and the likelihood of issuing management earnings forecast as a dependent variable.

Table 3 shows the results of the ANCOVA which indicate that the main effect of accounting knowledge is statistically significant $(p=0.01)$ and the interaction effect of accounting knowledge and attribution is marginally significant $(p=0.08)$. However, the effect of years of work experience on the likelihood of issuing management earnings forecast is not significant $(p=0.29)$. These results suggest that after controlling years of work experience, the effect of accounting knowledge confirm the main findings.

Table 3: The Likelihood of Issuing Management Earnings Forecasts

Panel A: Two-way ANCOVA - Years of working experience = a covariate

\begin{tabular}{lrrrrc}
\hline Sources & $\begin{array}{c}\text { Sum of } \\
\text { Squares }\end{array}$ & Df & $\begin{array}{c}\text { Mean } \\
\text { Square }\end{array}$ & F-statistics & p-value \\
\hline Knowledge & 19.83 & 1 & 19.83 & 6.82 & $0.01^{* *}$ \\
Attribution & 3.09 & 1 & 3.09 & 1.06 & 0.31 \\
Knowledge x Attribution & 9.59 & 1 & 9.59 & 3.30 & $0.08^{*}$ \\
Experience (covariate) & 3.30 & 1 & 3.30 & 1.13 & 0.29 \\
Error & 154.12 & 53 & 2.91 & & \\
\hline
\end{tabular}

Note: Dependent variable $=$ the likelihood of issuing management earnings forecasts. The participants were asked to specify the likelihood of issuing management earnings forecast using an 11-point (0-10) Likert scale denoting 'not at all likely' to 'extremely likely'. Total likelihood is $100 \%$. *** ** and * denote $1 \%, 5 \%$ and $10 \%$ significance levels, respectively.

\subsection{Additional Analysis}

\subsubsection{Debriefing}

In general, managers have their own personal preferences and concerns with regards to the disclosure of earnings forecasts (Aboody \& Kasznik, 2000; Hirst et al., 2008; Kothari et al., 2009; Wang \& Tan, 2013). In the 
current study, participants are asked to respond to six additional postexperimental Likert-scale questions (debriefing questions) which emphasise on the ramifications associated with their disclosure and nondisclosure decisions. The debriefing questions are on an 11-point (0-10) Likert scale, where 0 denotes, 'not at all concerned' and 10 denotes, 'extremely concerned'.

A correlation analysis (untabulated) indicates a high correlation between the six debriefing questions. Therefore, the principal component analysis (PCA) is used to organise the variables into the same construct. The untabulated PCA results indicate three constructs, consisting of market expectation, reputation and forecast accuracy concerns (chisquare $=44.20, \mathrm{p}=0.00$, eigenvalues $=1.72,1.63$ and 1.13 , respectively). The three constructs are further analysed.

Table 4 tabulates the planned comparison results of the degrees of consideration regarding the ramifications associated with the disclosure and non-disclosure decisions. The low accounting knowledge group exhibits a significantly lower concern for forecast accuracy than the high accounting knowledge group ( $\mathrm{p}=0.02$, one-tailed). In contrast, the market expectation and reputation constructs are insignificantly different between the low and high accounting knowledge groups $(p=0.34$ and 0.15 , one-tailed, respectively). Overall, the results show that

Table 4: The Effect of Consideration on the Ramifications Associated with Disclosure Decisions between Low and High Accounting Knowledge

Descriptive - Mean (Standard Deviation) and Planned Comparisons

\begin{tabular}{lcccc}
\hline Considerations & \multicolumn{2}{c}{ Accounting Knowledge } & t-statistics & p-value \\
\cline { 2 - 3 } & Low & High & & \\
\hline Accuracy & $5.91(1.52)$ & $6.83(1.69)$ & -2.18 & $0.02^{* *}$ \\
& $\mathrm{~N}=32$ & $\mathrm{~N}=26$ & & \\
Market expectation & $6.73(1.50)$ & $6.52(2.38)$ & 0.42 & 0.34 \\
& $\mathrm{~N}=32$ & $\mathrm{~N}=26$ & & \\
Reputation & $6.70(2.42)$ & $7.29(1.74)$ & -1.03 & 0.15 \\
& $\mathrm{~N}=32$ & $\mathrm{~N}=26$ & & \\
\hline
\end{tabular}

Note: The two groups of participants were asked to specify their degree of consideration with regard to market expectations, reputation and forecast accuracy using an 11-point (0-10) Likert scale, where 0 and 10 denote 'not at all concerned' and

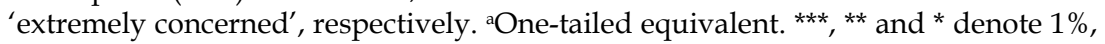
$5 \%$ and $10 \%$ significance levels, respectively. 
the group with low accounting knowledge is less likely to issue earnings forecasts, and they express less concerns with regard to the accuracy of the forecasts, as compared to those with high accounting knowledge. The findings are consistent with prior evidence. This indicates that some managers intend to issue biased earnings forecasts to meet or beat market expectations (Aboody \& Kasznik, 2000; Wang \& Tan, 2013).

\subsubsection{Forecast Horizon}

Forecast horizons play a role in earnings forecast bias, such that quarterly earnings forecasts tend to be more pessimistically biased than longer-term forecasts (Rogers \& Stocken, 2005). As a result, this study also performs an additional test to examine the effect of self-serving attributions and accounting knowledge on the likelihood of issuing a longer-term management earnings forecast (half a year). Participants are asked the likelihood of issuing an earnings forecast on a half-year basis, using an 11-point (0-10) Likert scale question, where 0 denotes, 'not at all likely' and 10 denotes, 'extremely likely'. The untabulated results suggested that accounting knowledge and attributions have no significant effect on the extended forecast horizon (F statistic $=1.16$, $\mathrm{p}=0.33)$.

\section{Discussion and Implications}

Previous studies have noted non-mutually conclusive results between bad news and disclosure behaviours. Some studies (Kasznik \& Lev, 1995; Skinner, 1994) argued that bad news motivated the managers to disclose information early due to the potential for litigation, and the impact on reputation. Other studies (Graham et al., 2005; Kothari et al., 2009) agreed that managers withhold or delay bad news for as long as possible because of their own career concerns or self-interests. The findings of this study have shown that the likelihood of managers issuing bad news earnings forecast varied according to the individual's accounting knowledge. Managers with high accounting knowledge are willing to disclose their private information while managers with low accounting knowledge tend to apply strategic disclosure behaviour by withholding future earnings failure. The current results contribute to prior literature in that it shows that managers' accounting background knowledge is one of the characteristics that has an important role in influencing the managers into making voluntary disclosures, particularly when the news 
is bad. Prior research (Nelson, 1993; Rose \& Rose, 2008) has indicated that one's accounting knowledge affects one's judgment and one's ability to do accounting-related tasks and the outcome drawn from this study certainly supported the claim that accounting knowledge benefits voluntary disclosure decisions. The emphasis of equality and fairness in financial reporting, and the importance of being accountable to all the stakeholders, should be contained within the contents of all basic accounting courses because this is one way to raise the consciousness of accounting students into being an accountable professional. This quality can enhance the managers' willingness to voluntarily disclose the significant information to their market investors.

This study also provides evidence which shows the effect of selfserving attribution on the management's judgment and disclosure decision. The findings further indicate that managers' willingness to issue earnings forecasts is not affected by the internal or external attribution. Psychology literature (Gurevich et al., 2012) on attribution has suggested that causal attribution plays a role in the aforementioned decision; causal attribution deviates from such decisions as stated in the game theory prediction which involves sharing gains between parties. Nonetheless, the results of this study are not congruent with Libby and Rennekamp (2012) who had observed that individuals engaged in the self-serving attribution bias by relating their favourable performance to internal factors and their unfavourable performance to external factors. This study also provides evidence which shows that the JDM is not affected by causal attribution. Therefore, as decision makers, managers do not engage in self-serving bias when making decisions regarding voluntary disclosure. The results generated from this study may be explained by how the response variable in the task was measured. Since participants are asked to indicate their likelihood of issuing a management earnings forecast, not a specific forecast number, their responses could not be determined to be right or wrong outcomes. In sum, this study also expands on prior literature by highlighting that self-serving attributions do not influence the individual's judgment and decisionmaking when the consequent outcome cannot be measured or justified.

When focusing on the interactive effects of accounting knowledge and attribution, this study observes that these factors jointly influence the manager's willingness to issue earnings forecasts. Specifically, the effect of self-serving attribution bias on the likelihood of issuing management earnings forecast is conditional on the manager's level of accounting knowledge. Low accounting knowledge managers engage in self-serving 
bias that referred to the internal causes of future earnings failures; they also produce strategic disclosures by withholding information. On the other hand, when facing an external cause of future earnings failures, low accounting knowledge managers are more willing to disclose their future earnings failure because they can attribute the earnings failure to an external cause. However, self-serving attribution bias does not seem to have the same effect on high accounting knowledge managers. In this regard, the likelihood of high accounting knowledge managers issuing future earnings information in the presence of either the internal or external factors, remained intact. This study combines the findings noted in motivated reasoning and attribution literature by providing evidence to show that accounting background knowledge can guide the decision maker's judgment into following accuracy motives, and into providing the timely disclosures of bad news earnings forecasts. Even though the effects of the internal and external causes could not be equally weighed, based on the individual's perception (Miller \& Ross, 1975), the outcome of this study extends previous findings, in that the impact of self-serving attribution bias was contingent on the individual's background knowledge. The level of accounting knowledge helps to mitigate the self-serving attribution bias, such that managers with high accounting knowledge are less inclined to attribute bad results to internal causes. They are, however, more likely than those with low accounting knowledge, to disclose earnings forecasts, regardless of the results or causes. Therefore, the findings of this study contribute to existing attribution literature by zooming in on the relationship between accounting knowledge and self-serving attribution, both of which could be applied to make voluntary disclosure decisions.

Previous behavioural literature (Libby \& Luft, 1993) in accounting have suggested that more accounting knowledge and more years of work experience contribute to better decision-making in accounting tasks. From the additional analysis conducted, this study is also able to mitigate the confounding effect of knowledge and experience on management disclosure decisions. The variable of years of work experience is used as a covariate. The results confirm the main findings. In addition, this study also examines the effects of accounting knowledge and self-serving attribution on the likelihood of issuing a longerterm management earnings forecast (i.e., half a year). The results also show that accounting knowledge and self-serving attribution have no significant impact on the extended forecast horizon. The current findings are, thus, consistent with previous findings which asserted 
that managers tend to disclose bad news forecasts early in the shortterm forecast horizon (quarterly) instead of the longer-period forecast horizon. Overall, the findings of this study potentially contribute to both the voluntary disclosure literature and related regulations involving forward-looking information.

\section{Conclusions and Limitations}

This experimental study investigates the effects of accounting knowledge (low and high) and self-serving attribution (internal and external) on the likelihood of issuing quarterly management earnings forecasts. The attribution accounted for is either internal or external, and the level of accounting knowledge is low or high, proxied by the MBA (low) and MACC students (high), whose accounting background knowledge is statistically different.

The results reveal that the level of accounting knowledge influences the managers' decision to disclose earnings forecasts when facing future earnings disappointment. High accounting knowledge managers are more likely to disclose earnings forecasts. The likelihood of managers issuing earnings forecasts do not differ, whether the cause is attributed to the internal or external factor. However, accounting knowledge and self-serving attribution have a joint effect on the managers' willingness to issue earnings forecast. Low accounting knowledge managers impose more bias on earnings forecast; they are less likely to issue earnings forecast when the results are attributed to internal causes. However, high accounting knowledge managers are more likely to issue future earnings information, regardless of the causes (internal or external). Despite controlling the years of work experience as the covariate, the results are still robust.

This experimental study, however, encountered three limitations. First, this study evaluates the accounting knowledge of the participants based on the number of accounting courses taken, rather than on the results of an accounting knowledge test. However, this weakness is supported by an experimental methodology that contained tight controls (e.g., control for years of work experience and business and finance knowledge). Second, this study does not take into account the impact of forecast frequency. Instead, it is restricted to a single forecast frequency (i.e., quarterly forecast). Subsequent research could investigate the moderating effect of forecast frequency on the likelihood of issuing management earnings forecasts. Third, this study does not investigate 
the impact of accounting knowledge on the level of earnings forecast accuracy. Future research could explore whether managers with high accounting knowledge or a stronger background, produce more accurate earnings forecasts or put less bias on earnings forecasts.

\section{References}

Aboody, D., \& Kasznik, R. (2000). CEO stock option awards and the timing of corporate voluntary disclosures. Journal of Accounting and Economics, 29(1), 73-100. http://dx.doi.org/10.1016/S0165-4101(00)00014-8

Baginski, S.P., Hassell, J.M., \& Hillison, W.A. (2000). Voluntary causal disclosures: Tendencies and capital market reaction. Review of Quantitative Finance and Accounting, 15(4), 371-389. http://dx.doi.org/10.1023/A:101 2002608615

Baginski, S.P., Hassell, J.M., \& Kimbrough, M.D. (2004). Why do managers explain their earnings forecasts? Journal of Accounting Research, 42(1), 1-29. http://dx.doi.org/10.1111/j.1475-679X.2004.00127.x

Barton, J., \& Mercer, M. (2005). To blame or not to blame: Analysts' reactions to external explanations for poor financial performance. Journal of Accounting and Economics, 39(3), 509-533. http://dx.doi.org/10.1016/j. jacceco.2005.04.006

Bettman, J.R., \& Weitz, B.A. (1983). Attributions in the board room: Causal reasoning in corporate annual reports. Administrative Science Quarterly, 28(2), 165-183. http://dx.doi.org/10.2307/2392616

Bonner, S.E. (1990). Experience effects in auditing: The role of task-specific knowledge. The Accounting Review, 65(1), 72-92.

Bonner, S.E. (2008). Judgment and decision making in accounting. Accounting Horizons, 13(4), 385-398. http:/ / dx.doi.org/10.2308/acch.1999.13.4.385

Bonner, S.E., \& Lewis, B.L. (1990). Determinants of auditor expertise. Journal of Accounting Research, 28, 1-20. http://dx.doi.org/10.2307/2491243

Bozanic, Z., Roulstone, D.T., \& Van Buskirk, A. (2018). Management earnings forecasts and other forward-looking statements. Journal of Accounting and Economics, 65(1), 1-20. http://dx.doi.org/10.1016/j.jacceco.2017.11.008

Chen, W., Han, J., \& Tan, H-T. (2016). Investor reactions to management earnings guidance attributions: The effects of news valence, attribution locus, and outcome controllability. Accounting, Organizations and Society, 55(November), 83-95. http://dx.doi.org/10.1016/j.aos.2016.10.002

Fischer, M., \& Rosenzweig, K. (1995). Attitudes of students and accounting practitioners concerning the ethical acceptability of earnings management. Journal of Business Ethics, 14(6), 433-444. http://dx.doi.org/10.1007/ BF00872085

Gollwitzer, P.M., \& Moskowitz, G.B. (1996). Goal effects on action and cognition. In E.T. Higgins \& A.W. Kruglanski (Eds.), Social psychology: Handbook of basic principles (pp. 361-399). New York, NY: Guilford Press. 
Graham, J.R., Harvey, C.R., \& Rajgopal, S. (2005). The economic implications of corporate financial reporting. Journal of Accounting and Economics, 40(1-3), 3-73. http:/ / dx.doi.org/10.1016/j.jacceco.2005.01.002

Gurevich, G., Kliger, D., \& Weiner, B. (2012). The role of attribution of causality in economic decision making. The Journal of Socio-Economics, 41(4), 439-444. http:/ / dx.doi.org/10.1016/j.socec.2011.07.005

Han, J. (2013). A literature synthesis of experimental studies on management earnings guidance. Journal of Accounting Literature, 31(1), 49-70. http:// dx.doi.org/10.1016/j.acclit.2013.06.003

Heider, F. (1958). The psychology of interpersonal relations. Hoboken, NJ: John Wiley \& Sons Inc. http:/ / dx.doi.org/10.1037/10628-000

Hirst, D.E., Koonce, L., \& Venkataraman, S. (2008). Management earnings forecasts: A review and framework. Accounting Horizons, 22(3), 315-338. http:/ / dx.doi.org/10.2308/acch.2008.22.3.315

Houston, J.F., Lev, B., \& Tucker, J.W. (2010). To guide or not to guide? Causes and consequences of stopping quarterly earnings guidance. Contemporary Accounting Research, 27(1), 143-185. http://dx.doi.org/10.1111/j.19113846.2010.01005.x

Kasznik, R., \& Lev, B. (1995). To warn or not to warn: Management disclosures in the face of an earnings surprise. The Accounting Review, 70(1), 113-134.

Kimbrough, M.D., \& Wang, I.Y. (2014). Are seemingly self-serving attributions in earnings press releases plausible? Empirical evidence. The Accounting Review, 89(2), 635-667. http:/ / dx.doi.org/10.2308/accr-50628

King, R., Pownall, G., \& Waymire, G. (1990). Expectations adjustment via timely management forecasts: Review, synthesis, and suggestions for future research. Journal of Accounting Literature, 9(1), 113-144.

Kothari, S.P., Shu, S., \& Wysocki, P.D. (2009). Do managers withhold bad news? Journal of Accounting Research, 47(1), 241-276. http://dx.doi.org/10.1111/ j.1475-679X.2008.00318.x

Kunda, Z. (1990). The case for motivated reasoning. Psychological Bulletin, 108(3), 480-498. http:/ / dx.doi.org/10.1037/0033-2909.108.3.480

Kundra, Z., \& Sinclair, L. (1999). Motivated reasoning with stereotypes: Activation, application, and inhibition. Psychological Inquiry, 10(1), 12-22. http:/ / dx.doi.org/10.1207/s15327965pli1001_2

Lang, M.H., \& Lundholm, R.J. (2000). Voluntary disclosure and equity offerings: Reducing information asymmetry or hyping the stock? Contemporary Accounting Research, 17(4), 623-662. http:/ / dx.doi.org/10.1506/9N45-F0JXAXVW-LBWJ

Lev, B. (2003). Corporate earnings: Facts and fiction. Journal of Economic Perspectives, 17(2), 27-50. http:/ / dx.doi.org/10.1257/089533003765888412

Lev, B., \& Penman, S.H. (1990). Voluntary forecast disclosure, nondisclosure, and stock prices. Journal of Accounting Research, 28(1), 49-76. http:/ / dx.doi. org/10.2307/2491217

Libby, R., \& Luft, J. (1993). Determinants of judgment performance in accounting settings: Ability, knowledge, motivation, and environment. Accounting, 
Organizations and Society, 18(5), 425-450. http://dx.doi.org/ 10.1016/03613682(93)90040-D

Libby, R., \& Rennekamp, K. (2012). Self-serving attribution bias, overconfidence, and the issuance of management forecasts. Journal of Accounting Research, 50(1), 197-231. http://dx.doi.org/10.1111/j.1475-679X.2011.00430.x

Merkl-Davies, D.M., \& Brennan, N.M. (2007). Discretionary disclosure strategies in corporate narratives: incremental information or impression management? Journal of Accounting Literature, 27, 116-196.

Miller, D.T., \& Ross, M. (1975). Self-serving biases in the attribution of causality: Fact or fiction? Psychological Bulletin, 82(2), 213-225. http://dx.doi. org/10.1037/h0076486

Miller, G.S. (2002). Earnings performance and discretionary disclosure. Journal of Accounting Research, 40(1), 173-204. http://dx.doi.org/10.1111/1475679X.00043

Nelson, M.W. (1993). The effects of error frequency and accounting knowledge on error diagnosis in analytical review. The Accounting Review, 68(4), 804824.

Picur, R.D. (2007). The effects of accounting knowledge on the omission of value added information in wealth measurement and distribution decisions. Review of Accounting and Finance, 6(1), 15-23. http://dx.doi. org/10.1108/14757700710725430

Rogers, J.L., \& Stocken, P.C. (2005). Credibility of management forecasts. The Accounting Review, 80(4), 1233-1260. http://dx.doi.org/10.2308/ accr.2005.80.4.1233

Rose, A.M., \& Rose, J.M. (2008). Management attempts to avoid accounting disclosure oversight: The effects of trust and knowledge on corporate directors' governance ability. Journal of Business Ethics, 83(2), 193-205. http:/ /dx.doi.org/10.1007/s10551-007-9611-1

Roychowdhury, S., \& Sletten, E. (2012). Voluntary disclosure incentives and earnings informativeness. The Accounting Review, 87(5), 1679-1708. http:/ / dx.doi.org/10.2308/accr-50189

Skinner, D.J. (1994). Why firms voluntarily disclose bad news. Journal of Accounting Research, 32(1), 38-60. http://dx.doi.org/10.2307/2491386

Skinner, D.J. (1997). Earnings disclosures and stockholder lawsuits. Journal of Accounting and Economics, 23(3), 249-282. http://dx.doi.org/10.1016/ S0165-4101(97)00010-4

Vera-Munoz, S.C. (1998). The effects of accounting knowledge and context on the omission of opportunity costs in resource allocation decisions. Accounting Review, 73(1), 47-72.

Wang, E.Y., \& Tan, H-T. (2013). The effects of guidance frequency and guidance goal on managerial decisions. Journal of Accounting Research, 51(3), 673-700. http:/ / dx.doi.org/10.1111/j.1475-679X.2012.00470.x

Weiner, B. (1985). An attributional theory of achievement motivation and emotion. Psychological Review, 92(4), 548-573. 


\section{Appendix: Experimental Materials}

\section{Definition of Management Earnings Forecast}

Management earnings forecast is a voluntary managerial disclosure concerned with a firm's expected performance prior to actual performance announcement. Issuance of earnings forecast is voluntary (i.e. not required by law).

\section{PART 1 \\ BACKGROUND INFORMATION}

We Electronics Public Company Limited (hereafter, "We Electronics" or "the Company") is a leading electronics parts manufacturer and distributor. The core products include circuit boards, electric circuitry, automotive electronics and electronic instruments. Domestic sales account for 60 per cent of its revenue and the remaining 40 per cent from exports to the European market. We Electronics' business has grown steadily over the last five years, and its stocks are traded on the Stock Exchange of Thailand (SET). However, the Company is facing fierce competition from other players in the industry.

Table A1: We Electronics' Earnings History

\begin{tabular}{lccr}
\hline Annual Income Statement (partial) & \multicolumn{3}{c}{ (in million baht, except per share data) } \\
\hline Year Ended & 2014 & 2015 & 2016 \\
\hline Net Sales & 9,294 & 11,284 & 12,449 \\
Gross profit & 2,451 & 3,567 & 3,914 \\
Net Income & 1,574 & 1,923 & 2,240 \\
Earnings Per Shares (EPS) & 3.60 & 3.90 & 4.10 \\
\hline
\end{tabular}

\section{Management Earnings Forecasts of We Electronics}

The forecast division has provided you with the earnings forecast information for the first quarter of 2017 (Q1 of 2017) for consideration. The quarterly earnings forecast is estimated based on the financial models that incorporate historical earnings patterns and other information. The financial consultant believes that the estimated earnings for the first quarter of 2017 would be realised at the 95 per cent confidence level. The expected earnings per share (EPS) for the first quarter of 2017 is 0.90 Baht. $(1 \mathrm{USD}=\mathrm{THB} 33)$ 
PART 2

\section{ADDITIONAL INFORMATION ABOUT WE ELECTRONICS}

\section{Analysts' Consensus Forecasts for We Electronics}

Because of the Company's continuous historical growth and interests from investors, We Electronics has attracted a following by certain financial analysts. The analysts have a positive view of the company's growth, and the analysts' consensus earnings per share (EPS) forecast for the first quarter of 2017 is 1.10 Baht.

\section{Management Earnings Forecasts of We Electronics}

The additional information for the first quarter earnings forecast (Q1 of 2017) is as follows:

\begin{tabular}{|lccc|}
\hline & $\begin{array}{c}\text { Actual earnings } \\
\text { of the last } \\
\text { quarter of 2016 }\end{array}$ & $\begin{array}{c}\text { Expected } \\
\text { earnings for } \\
\text { Q1 of 2017 }\end{array}$ & Change \\
\hline Earnings Per Share (THB) & 1.10 & 0.90 & $(0.20)$ \\
\hline
\end{tabular}

\section{Attribution Manipulation}

\section{Internal Attribution Condition}

The company expects the earnings per share (EPS) for the first quarter of 2017 to be below last quarter's actual earnings, which could largely be attributed to the company's marketing initiatives. The main competitor's new marketing activity plays a negligible role in the company's earnings expectation.

\section{External Attribution Condition}

The company expects the earnings per share (EPS) for the first quarter of 2017 to be below last quarter's actual earnings, which could largely be attributed to the main competitor's new marketing activity. The company's marketing initiatives play a negligible role in the company's earnings expectation.

\section{Response Variable Sheet}

Based on the aforesaid information about We Electronics Public Company Limited, please answer the following questions. 
As an executive manager of We Electronics, you are likely to "publicly issue management earnings forecast" for the first quarter of 2017. Please response with slash $(/)$ on the provided line that most describes your thought or opinion.

1
$\begin{aligned} & 0 \\ & \text { Not at all } \\ & \text { Likely }\end{aligned}$


